\title{
Glossary of major figures
}

The following individuals are among the most important of those mentioned in the text. Space precludes going into detail, but we hope by means of three or four short sentences at least to place them in the context of their time and work.

Louis ALTHUSSER (1918-90) French Marxist philosopher. Stressed scientific nature of Marxism. Knowledge was a 'production process' involving theoretical raw materials related to the society of the day and its particular circumstances. The economy determined knowledge only 'in the last resort'. Major works: For Marx (1969), Lenin and Philosophy, and Other Essays (1971).

St Thomas AQUINAS (c.1224-74) Italian Dominican friar and Aristotelian scholar. Major theologian and writer. Produced rational basis for arguing the existence of God. Very influential in the development of the concept of the just war. Strong believer in the moral basis of political activity. Major work: Summa Theologica (1266-73) (60 volumes).

Hannah ARENDT (1906-75) German-Jewish philosopher and political theorist. Fled Nazi Germany to the USA and became citizen. Particularly concerned with justice and order in society. Saw modern political thinking as having abandoned political values for social ones. Major works: The Origins of Totalitarianism (1951), On Revolution (1963), Eichmann in Jerusalem (1963).

ARISTOTLE (384-322Bc) Athenian scientist, educator and philosopher. Student of Plato and teacher of Alexander the Great of Macedon. Major figure in the study of politics. Classifier of political systems. Founded a university in Athens known as the Lyceum. Critical of radical democracy, preferring government by the educated and competent few. Major influence on the development of science until the Renaissance and on political science until the present. Major work: The Politics.

Clement ATTLEE, First Earl (1883-1967) Leader of the British Labour Party (193555), deputy prime minister during World War (1942-45), and prime minister (1945-51). As PM he led a government that established the welfare state, nationalised many key industries, began dismantling the British Empire, and authorised the British A-bomb project.

St AUGUSTINE of Hippo (354-430) Roman bishop, writer, rhetorician and theologian from North Africa. Defended the newly established state religion of Christianity against its critics. Only earthly state can protect men as God can. Politics and government seeks peace but can never replace Christianity as the true object of life. Evil in the world is the conscious decision to misuse free will. Major work: City of God (413-25). 
Caius Octavianus AUGUSTUS (63BC-AD14) Roman politician and statesman. Adopted son of Julius Caesar. Destroyed Caesar's assassins in civil war. Defeated Mark Antony and Cleopatra in another civil war. Became first Roman emperor. Restorer of the Roman world after a century of wars. One of the Western world's greatest - and most ruthless - political geniuses.

Michael BAKUNIN (1814-76) Russian anarchist, revolutionary and atheist. Opposed Marx in the First International. Saw state and religion as working together to oppress mankind. Identified need for free communities of people working together with communal property rights. Not a systematic thinker and writer. Never completed his major books.

Stanley BALDWIN, First Earl of Bewdley (1867-1947) British Conservative PM (1923-24, 1924-29, 1935-7). Dominated inter-war British politics. Symbol of political stability in the turmoil of the inter-war years. Chief figure in the abdication crisis of Edward VIII in 1936.

John BALL (d.1381) English priest and leader of the Peasants' Revolt (1381).

Simone de BEAUVOIR (1908-86) French feminist writer and philosopher. Author, among many other things, of The Second Sex (1949), which was a major influence on 'second-wave' feminism. Its key argument is that 'a woman is not born, but made'.

Samuel BEER (b.1911) Contemporary American political scientist. Specialist in British politics.

Daniel BELL (b.1919) American political scientist and sociologist. Neo-conservative polemicist. Argues that politics is not longer ideological, but is dominated by practical problems of economic growth and social reform. Suspicious of big government. Author of The End of Ideology (1960) and The Coming of Post-Industrial Society (1973).

Tony BENN (b.1925) British Labour politician, diarist, broadcaster. Minister in Labour governments in the 1960s and 1970s. On left of the party. Supporter of constitutional reform. Campaigned to become Labour leader in 1980s. Author of Arguments for Socialism (1980) and Arguments for Democracy (1981).

Jeremy BENTHAM (1748-1832) British Utilitarian philosopher and legal writer. Humans are motivated by self-interest and the pursuit of happiness. These are basis for democratic government, law and social policy. Great influence on nineteenth-century liberalism. Main works: Fragments on Government (1776) and Principles of Morals and Legislation (1789).

Sir Isaiah BERLIN (1909-97) British university teacher and writer. Great influence on liberal thought, especially his Two Concepts of Liberty (1957). Other major works: Karl Marx (1939), The Lion and the Fox (1953), Four Essays on Liberty (1969).

Eduard BERNSTEIN (1850-1932) German Social Democrat politician, journalist and leading thinker on revisionist socialism. Saw himself as modernising Marxism in light of modern developments. Sought a peaceful transition to socialism. Major work: Evolutionary Socialism (1898).

Sir William BEVERIDGE, First Baron Beveridge (1879-1963) British civil servant and economist. Chair of the Beveridge Committee that produced the 1942 White Paper on the establishment of the social security element of the welfare state. 
Otto von BISMARCK, Prince Bismarck, Duke of Lauenburg (1815-98) PrussianGerman statesman and creator of the Second German Empire (1871-1918).

Robert BLACHFORD (1851-1943) British leading figure in the early Independent Labour Party (ILP).

Tony BLAIR (b.1953) British Labour leader (1994-) and prime minister (1997-). Moderniser of Labour Party under banner of New Labour. Replaced Clause IV and the 'socialist' commitment to public ownership. Moved party to the right. Led party to landslide election victories in 1997 and 2001.

John BRIGHT (1811-89) British radical Quaker orator and politician. Along with Richard Cobden he was a leading figure in the Anti-Corn Law League that campaigned for free trade in the 1830s and 1840s.

John BRUCE-GLASIER (1859-1920) British Independent Labour Party figure.

Charles BUKOWSKI (1920-94) American poet and author.

Edmund BURKE (1729-97) British-Irish politician, thinker and writer. Usually identified as inspiring conservatism and its values. Great believer in social stability, limited government and gradual change, tradition. Supported many of the demands of the American colonists but was highly critical of the French Revolution. Major work: Reflections on the Revolution in France (1790).

George W. BUSH (b.1946) Republican president of the USA (2001-). Former governor of Texas. Seen as a right-wing conservative. Strong advocate of unilateralist American foreign policy initiatives such as National Missile Defense and withdrawal from some arms control and environmental treaties.

R. A. BUTLER, Richard Austin ('RAB'), and Baron Butler of Saffron Walden (1902-82) Senior British Conservative politician. On the liberal-left of the party. Responsible for Education Act (1944) and aided Conservative acceptance of the welfare state. With Labour's Hugh Gaitskell he gave his name to Butskellism to describe Conservative and Labour economic policies of the 1950s.

Rachel CARSON (1907-64) American scientist, biologist and writer. Major work: Silent Spring (1962).

Houston Stewart CHAMBERLAIN (1855-1927) British, later German, writer on racist structuring of human society. Saw Germanic peoples as superior. Major work: The Foundations of the Nineteenth Century (1899). Much admired in Nazi Germany as an influential thinker on racial theory.

Joseph CHAMBERLAIN (1836-1914) British Radical and, later, Conservative politician. Made his reputation as a social reformer in Birmingham politics. A leading political figure of his time. Campaigned against Irish Home Rule and for partial trade protection measures.

CHARLEMAGNE, Charles the Great (742-814) King of the Franks. Created an empire that covered most of modern France, Belgium, the Netherlands, Germany and parts of Spain and Italy. Holy Roman Emperor (800-814). Seen as an early advocate of a united Europe. 
Winston Spencer CHURCHILL (1874-1965) Conservative, Liberal and again Conservative politician and statesman. Major twentieth-century British political figure. Nobel Prize winner. Soldier, historian, orator, writer. Held several government posts over a long political career: home secretary, first lord of the Admiralty, minister of munitions, lord chancellor and several others. Prime minister (1940-45 and 1951-55). Crucial role as war leader in the Second World War. Wrote A History of the English Speaking Peoples, memoirs of both world wars, a biography of Marlborough and many other articles and books.

Marcus Tullius CICERO (106-43BC) Roman writer, orator, lawyer, statesman and philosopher. Major figure during the last century of the Roman Republic. Held many senior government posts. Put down the Cateline Conspiracy to overthrow the state. Opponent of Julius Caesar and later Mark Antony and Octavian. Executed by Mark Antony. Surviving writings include Letters, Speeches.

Richard COBDEN (1804-65) British manufacturer and politician. With John Bright, the leading advocate of free trade and the Anti-Corn Law League. His campaign, resulting in the repeal of the Corn Laws in 1846, ruined him financially.

G. D. H. COLE, George Douglas Howard (1889-1959) British economist, journalist and academic. Leading social-democratic thinker. Advocated 'Guild Socialism', a cooperative system co-ordinated by the state. Wrote A History of Socialist Thought (1953) and many studies of Fabian and Marxist socialism, as well as contributing to practical ideas for social improvement.

Bernard CRICK (b.1929) Former British professor of politics. Major works: In Defence of Politics (1962), Essay on Citizenship (2000).

Anthony CROSLAND (1918-77) British Labour politician, economist and writer. Social-democratic thinker and writer. Held many government posts: foreign secretary, education secretary, local government minister. Wrote The Future of Socialism (1956).

Charles DARWIN (1808-82) British naturalist. Theorist on evolution, based on researches conducted on world voyage in the Beagle. Major work was The Origin of Species (1859). Ideas on 'natural selection' as the engine of evolution were distorted by late nineteenth-century political thinkers into the concept of 'Social Darwinism' to advocate racism, imperialism and class domination.

Jacques DELORS (b.1925) French politician and civil servant. President of the European Commission (1985-95). Strong advocate of European Union. Formulated 'Delors Plan' for the creation of a single European currency.

Jacques DERRIDA (b.1930) French linguistic philosopher, literary critic and psychoanalyst. Major work: Margins of Philosophy (1972).

René DESCARTES (1596-1650) French mathematician and philosopher. Challenged the scholarly tradition and dogmas of his day. Sought to understand the basis for truth. Cartesian philosophy can be summed up in his phrase, 'I think, therefore I am'.

Charles DICKENS (1812-70) British novelist. Massive number of novels and letters. Supporter of social reform and social justice. Best-known writings: Oliver Twist (1837), A 
Christmas Carol (1843), Great Expectations (1860-1), A Tale of Two Cities (1859, David Copperfield (1849-50).

Benjamin DISRAELI, First Earl of Beaconsfield (1804-81) British Conservative politician. Novelist: Coningsby (1844) and Sybil (1845). Coined notion of 'two nations' in Britain that modern Conservatism should strive to bring together. Hence, creator of 'onenation conservatism'. Prime minister (1868 and 1874-80). Popular imperialist and advocate of a greater role for skilled working-class people in the democratic process (under Conservative leadership).

lain DUNCAN SMITH (b.1954) British Conservative politician. Party leader (2001-).

Ronald DWORKIN (b.1931) Lawyer and jurist. Major work: Taking Rights Seriously (1978).

Paul EHRLICH (b.1932) American population biologist. Author of many works on environmental and population matters, most notably The Population Bomb (1968).

T. S. ELIOT, Thomas Stearns (1888-1965) American, later British, writer and poet. Politically, on the right: 'a classicist in literature, a royalist in politics and an Anglo-Catholic in religion'. Chief works include: Prufrock (1917), Murder in the Cathedral (1935), The Waste Land (1922), Four Quartets (1935-42).

Friedrich ENGELS (1820-95) German socialist. Part of the 'Manchester circle' of German industrialists. Major work: The Condition of the Working Class in England (1845). Collaborated with - and financially supported - Karl Marx. Many joint works on socialism and revolution. Major collaborative effort: The Communist Manifesto (1848). Worked to create a revolutionary workers' movement. Major role in establishing Marx's reputation after his death in 1883 .

Q. FABIUS MAXIMUS, CUNCATOR ('Delayer') (275?-203вC) Roman general during Second Punic War (218-201BC). Sought to defeat Carthaginians by delaying battle until such a time as would be most favourable to victory.

Louis FARRAKHAN, Louis Eugene Wolcott (Louis X) (b.1933) Black American leader of radical 'Nation of Islam'.

Johann Gottlieb FICHTE (1762-1814) German philosopher and nationalist. Seen as one of the intellectual ancestors of German nationalism in the nineteenth century and German totalitarianism in the twentieth.

Sir Robert FILMER (d.1653) English royalist. Defender of hereditary monarchy. Major work: Patriarcha: or the Natural Power of Kings (1680). John Locke's First Treatise on Government is a refutation of Filmer.

Michael FOOT (b.1913) British Labour politician and journalist. On left of the party. Leader of the Labour Party 1980-83.

Michel FOUCAULT (1926-84) French philosopher. Saw power as widely spread in society. Exercised within and outside formal political institutions in a manner that severely limits real choice. Actions become self-evident truths that ensure compliance by most people in being controlled. Major works: Power/Knowledge: Selected Interviews and other writings 1972-1977 (1980). 
Charles FOURIER (1772-1837) French utopian socialist, social reformer. Advocate of a system of associated enterprises as an alternative to capitalism.

Anatole FRANCE, Jacques Anatole François Thibault (1844-1924) French novelist, poet, critic. Nobel Prize winner (1921).

General Francisco FRANCO (1892-1975) Spanish general and Fascist dictator (1939-75).

Betty FRIEDAN (b.1921) American feminist writer and activist in 'second-wave' feminism. Founded National Organisation of Women (NOW). Author of The Feminine Mystique (1963).

Milton FRIEDMAN (b.1912) American economist. Leading member of 'Chicago School' of economics. Major theorist of tight monetary control by government ('monetarism'). Very influential on neo-liberal and New Right politics. Strong critic of Keynesianism. Chief works: Capitalism and Freedom (1962), and, with wife Rose, Free to Choose (1980).

Erich FROMM (1900-80) German psychoanalyst and social philosopher. His To Have and To Be (1979) discusses the drive to ownership and consumerism in a materialist society.

Francis FUKUYAMA (b.1952) American political writer on the right. Very influential in the US Republican Party and the New Right. Analyst for both US government and private business. Major work: The End of History and the Last Man (1992). Controversially claimed that liberal democracy was the end product of human political development - especially in the wake of the end of the Cold War.

Hugh GAITSKELL (1906-63) British Labour politician and economist, on right of the party. Labour leader 1955-63. Advocated reform of the Labour Party to make it more electable.

William Lloyd GARRISON (1805-79) American campaigner for the abolition of slavery.

José ORTEGA Y GASSET (1883-1955) Spanish philosopher and writer. Author of The Revolt of the Masses (1930), a critical account of mass society.

Charles de GAULLE (1890-1970) French general and statesman. Leader of Free French forces after fall of France (1940). First president of the Fifth Republic (1959-69). Suspicious of American domination of Western Europe. Rejected British applications to join the EEC in 1963 and 1967.

Ernest GELLNER (b.1925) Cambridge academic and social anthropologist. Major work: Nations and Nationalism (1983).

Sir lan GILMOUR, Lord Gilmour of Craigmillor (b.1926) British historian and Conservative politician on left of the party.

William Ewart GLADSTONE (1809-98) British Liberal politician and statesman, classical scholar. Chancellor of the exchequer, prime minister (1868-74, 1880-5, 1886, 1892-4). Dominated British politics throughout most of the nineteenth century. Strong supporter of liberal causes at home and abroad. Supported Irish Home Rule, failed to implement it in the face of opposition both within and outside the Liberal Party. 
Arthur GOBINEAU, Count Joseph Arthur de (1816-82) French aristocrat and racial theorist. His Essay on the Inequality of Human Races (1859) was highly influential on development of theories of racial hierarchy, and, later, on Nazi theories of racial superiority.

William GODWIN (1756-1836) British philosopher and political writer. Strong influence on anarchist and socialist thinking. Married Mary Wollstonecraft. Father of Mary Shelley, author of Frankenstein. Major work: An Enquiry Concerning Political Justice (1793).

Mikhail GORBACHEV (b.1931) Soviet politician and statesman. Last leader of the USSR (1985-91). Sought to reform the communist system and end the Cold War with the West. Began end of Soviet domination of Eastern Europe.

T. H. GREEN, Thomas Hill (1836-82) British philosopher and social reformer. Major influence on the development of New Liberalism. Critical of laissez-faire liberalism. Saw a limited role for the state in improving individual and social conditions. Major works: Prolegomena on Ethics (1883) and Lectures on the Principles of Political Obligation (1879-80).

Germaine GREER (b.1939) Australian feminist writer. Major works: The Female Eunuch (1970) and Sex and Destiny (1985).

William HAGUE (b.1961) British Conservative politician. Leader of the Conservative Party (1997-2001).

Lord HAILSHAM, Quintin HOGG (1907-2001) British Conservative politician and lawyer. Lord chancellor under Edward Heath and Margaret Thatcher. Supporter of constitutional reform. Wrote a number of books on British politics, notably Elective Dictatorship (1976) and Dilemma of Democracy (1977).

Keir HARDIE (1856-1915) British Labour politician. One of the founders of the Labour Party. First Labour MP.

Roy HATTERSLEY (b.1932) British Labour politician, journalist and commentator. Holder of several senior Cabinet posts.

Friedrich von HAYEK (1899-1992) British political philosopher and economist of Austrian descent. Strong believer in liberty. Major influence on neo-liberalism and New Right ideas of the 1980s and 1990s. Major works: The Road to Serfdom (1948), The Constitution of Liberty (1960) and Law, Legislation and Liberty (1979).

Denis HEALEY (b.1917) British Labour politician on right of the party. Has held many senior posts in government, notably defence minister, chancellor of the exchequer.

Sir Edward HEATH (b.1916) Senior Conservative politician and statesman. Tory Party leader 1965-75). Prime minister (1970-74). Deeply committed to British membership of the EU.

G. W. F. HEGEL, Georg Wilhelm Friedrich (1770-1831) German philosopher and university teacher. Very influential on nineteenth century thought, especially Marx. Developed model of dialectical thinking (hypothesis-antithesis-synthesis-hypothesis) as the way knowledge develops. Saw the state as an ethical ideal: 'The Divine Idea as it exists on earth'. Major works: Phenomenology of Spirit (1807) and Philosophy of Right (1821). 
Johann Gottfried HERDER (1744-1803) German poet, philosopher and theorist of nationalism. Major Romantic and anti-Enlightenment thinker. Saw nations as having a distinct cultural 'spirit', natural units into which humans are divided. Strongly anti-state as it crushes national spirit.

Heinrich HIMMLER (1900-45) German Nazi leader of the SS. Played a key role in the organisation of the state terror and extermination of Jews and others as part of Hitler's New Order in Europe. Condemned to death at Nuremburg war crimes trials. Committed suicide.

Adolf HITLER (1889-1945) German leader of the Nazi Party. Created it as powerful political force. Chancellor of Germany (1933-45). Instituted totalitarian dictatorship and the suppression of opposition parties and organisations. Persecutions and attempted extermination of Jews and others identified as 'sub-humans'. Ideas clearly laid out in My Struggle (1925). Committed suicide.

Thomas HOBBES (1588-1679) English political philosopher, mathematician and classical scholar. Lived through the Civil Wars, Cromwell's rule and the Restoration. Argued for a strong state to ensure order in society. Suspicious of democracy as leading to strife and civil war. Major work: Leviathan (1651).

L. T. HOBHOUSE, Leonard Trelawney (1864-1929) British sociologist, academic and journalist. Leading influence on development of New Liberalism. Strong role for the state in promoting individual liberty and social good. Major works: The Theory of Knowledge (1896), Morals in Education (1906), Development and Purpose (1913).

J. A. HOBSON, John Atkinson (1858-1940) British economist and writer of economics and sociology. Made significant contribution to New Liberalism. Major works: The Evolution of Modern Capitalism: a Study of Machine Production (1894), Imperialism (1902).

\section{Quintin HOGG, see Lord Hailsham}

Saddam HUSSEIN (b.1937) President of Iraq (1969-2003).

H. M. HYNDMAN, Henry Mayers (1841-1931) British socialist leader. Helped found (Social) Democratic Federation (1881). Left to form National Socialists (1916). Defender of Marxism in several books.

Thomas JEFFERSON (1743-1826) Third American president (1801-9). Major figure in the American Revolution and War of Independence (1776-83). Helped draft Declaration of Independence (1776).

Peter JENKINS (b.1934) British journalist, political commentator and broadcaster.

Sir Keith JOSEPH (1918-95) British Conservative politician. Held senior Cabinet posts under PMs Heath and Thatcher. Major influence on development of New Right and neo-liberal opinions in the Conservative Party during the 1980s.

Karl KAUTSKY (1854-1938) German Social Democratic journalist, theorist and politician. Strong Marxist element to his thought when he was young. Became less of a Marxist in later life.

Alesander KERENSKY (1881-1970) Russian socialist. Led Russian government after 
the overthrow of the tsar from May to November 1917. Fled Russia when Bolsheviks seized power. Settled in USA.

John Maynard KEYNES, First Baron (1883-1946) British economist of New Liberal views. Major influence on the social-democratic consensus and on mid-twentieth-century economic thought by his Treatise on Money (1930) and The General Theory of Employment, Interest and Money (1936). Stressed the importance of using state economic levers to ensure full employment.

Nikita S. KHRUSHCHEV (1894-1971) Soviet politician and statesman. Became Soviet leader soon after the death of Stalin (1953). Began de-Stalinisation process at home and improvement of relations with the West abroad. Built Berlin Wall (1961). Overthrown in 1964 after perceived failures, including the Cuban Missile Crisis (1962).

Neil KINNOCK (b.1942) British Labour politician. Leader (1983-92). European commissioner.

Peter KROPOTKIN (1842-1921) Russian aristocrat, explorer, geographer and anarchist thinker and writer. Argued for the creation of a society of self-sufficient communities. Major works: The Conquest of Bread (1906), Fields, Factories and Workshops (1901) and Mutual Aid (1902).

Harold J. LASKI (1883-1950) British socialist writer, academic and Labour politician on the left of the party. Major work: Democracy in Crisis (1933).

V. I. LENIN (Vladimir Ilyich ULYANOV) (1870-1924) Russian revolutionary leader of the Bolsheviks (1893-1917) and Soviet leader (1917-24). Major reviser of Marxism in voluminous writings. Created concept of a revolutionary elite to lead the working classes in revolution. Major works: The Development of Capitalism in Russia (1899), What Is To Be Done? (1902), Imperialism: The Highest Stage of Capitalism (1916).

Jean-Marie LE PEN (b.1928) French politician. Leader of the French National Front, a party of the far right.

Primo LEVI (1919-87) Italian writer, chemist and commentator. Survivor of Auschwitz. Wrote accounts of his experiences in books such as If This Is A Man (1947) and If Not Now, When? (1982).

David LLOYD GEORGE, First Earl of Dwyfor (1863-1945) British Liberal politician and statesman. As chancellor of the exchequer in 1909 introduced National Insurance as part of the 'People's Budget'. Prime minister (1916-22). One of main figures at the Versailles Peace Conference (1919).

John LOCKE (1632-1704) English liberal political philosopher, epistemologist, medical and psychological researcher. His political writings stressed tolerance, the existence of natural rights, the importance of property, the need for representative government, justification for revolt. Very influential in British and American political thought. Major works: Essay Concerning Human Understanding (1690), A Letter Concerning Toleration (1689), Two Treatises on Government (1690).

LOUIS XIV (1638-1715) French monarch. Established the principle of 'absolutism' after many years of domestic conflict. Dominated Europe. 
James LOVELOCK (b.1919) British scientist and writer. Developed the 'Gaia Hypothesis' that sees the planet as a living, self-regulating system.

Georg LUKÁCS (1885-1971) Hungarian philosopher and critic. Marxist theorist. Stalinist and supporter of the infallibility of the Communist Party. Major work: History and Class Consciousness (1923).

James Ramsay MACDONALD (1866-1937) British Labour politician. A founder of the Labour Party. Prime minister (1924, 1929-31 and 1931-5). His forming and leadership of a Conservative-dominated coalition government in 1931 split the Labour Party.

Niccolo MACHIAVELLI (1469-1527) Italian/Florentine writer, public official, diplomat and playwright. Advocate of Italian unity. Established many of the major theoretical principles of modern political science. Developed a theory on state power and how to get and keep it. In his major works, The Prince and The Discourses on Livy, was seen to advocate an immoral and wicked approach to practical politics. The church placed his works on the Index of banned books after his death.

Alistair MACINTYRE (b.1929) British academic and philosopher. Major works: Short History of Ethics (1963), Secularism and Moral Change (1967).

Iain MACLEOD (1913-70) British Conservative politician on 'one nation' wing of the party.

Harold MACMILLAN, First Earl of Stockton (1894-1986) British Conservative politician. Held many senior posts in government. Prime minister (1957-63). In retirement was very critical of Mrs Thatcher's social and economic policies.

John MAJOR (b.1943) British Conservative politician. Held several senior government posts before becoming Prime minister (1990-7).

Rev. Thomas R. MALTHUS (1766-1834) British economist. Supporter of liberal economic principles. His rather gloomy Essay on the Principles of Population (1798) argued that population would tend to outstrip food supply unless kept under control.

MAO ZEDONG (1893-1976) Chinese nationalist and communist leader. Leader of China (1949-76). Revised Marxist-Leninist thinking to claim that revolution can occur in a peasant as well as an industrial society. Believed in continuous revolution of the masses. Stirred up the disastrous 'Cultural Revolution' in China during the 1960s.

Herbert MARCUSE (1898-1979) German neo-Marxist political philosopher. Strong critic of industrial capitalism and its oppression. Stressed revolutionary potential of groups other than the working classes. Major works: Reason and Revolution (1941), Eros and Civilisation (1958) and One Dimensional Man: Studies in the Ideology of Advanced Capitalist Society (1964).

Karl MARX (1818-83) German revolutionary socialist. Highly methodical and original thinker. Major sociologist, historian and economist. Journalist and political activist. Collaborated with Friedrich Engels on development of socialist theory and critical analysis of capitalism. Voluminous writer. The greatest single influence on the development of socialist thought in the nineteenth and twentieth centuries. Major works: German Ideology (1846), Communist Manifesto (1848), Capital (1867, 1885, 1894). 
Giuseppe MAZZINI (1805-72) Italian nationalist leader, revolutionary, republican and fighter for Italian unity and independence. Believed that world peace would follow when all peoples lived under their own national governments.

Friedrich MEINECKE (1862-1954) German historian. Distinguished between 'cultural nations' and 'political nations'. The former tend to have strong cultural unity, the latter are more open. Major work: Cosmopolitanism and the National State (1907).

Robert MICHELS (1876-1936) German sociologist. In Political Parties (1911) Michels developed his 'iron law of oligarchy': all organisations, however democratic or socialist, are essentially run by specialised oligarchies, dominating apathetic and subordinate members.

James MILL (1773-1836) British philosopher, radical and economist. Closely associated with Utilitarianism and classical liberalism. Supporter of the values of middle classes. Father of J. S. Mill.

J. S. MILL, John Stuart (1806-73) British Utilitarian and liberal philosopher, sometime MP. Great defender of individual freedom against tyrannical government and tyrannical public opinion. Supported votes for women and working-class rights. A considerable influence in development of liberal theory. Major works: On Liberty (1859), Considerations in Representative Government (1861), The Subjection of Women (1869).

Kate MILLET (b.1934) American feminist writer of 'second-wave' feminism. Major work: Sexual Politics (1970).

John MILTON (1608-74) English poet and political figure of the Civil Wars and Interregnum. Justified the trial and execution of Charles I in The Tenure of Kings and Magistrates (1649). Defended the principle of press freedom in Areopagitica (1644). Major poetical work: Paradise Lost (1667).

Juliet MITCHELL (b.1940) British Marxist socialist and feminist. Strong on interplay of economic, social and cultural elements in position of women in society. Major work: Women's Estate (1971).

Charles de Secondat, Baron de la Brede et de MONTESQUIEU (1689-1755) French philosopher. His Spirit of the Laws (1748) identified and discussed the concept of the 'Separation of Powers' of legislature, executive and judiciary. Great influence on American Constitution.

Thomas MORE (1478-1535) English statesman and writer. Chancellor under Henry VIII. Refused to recognise Henry as head of the Church of England. Executed. Major work: Utopia (1516).

William MORRIS (1834-96) British utopian socialist, poet and craftsman. Saw industrialisation as undermining the pleasure of craftsmanship. Founded Socialist League and Works and Crafts Movement.

Herbert MORRISON, Baron Morrison of Lambeth (1888-1965) Senior Labour politician of the 1930s and 1940s. Architect of nationalisation policies of the 1940s.

Gaetano MOSCA (1857-1941) Italian political sociologist and legal academic. Theorist of elitism. In The Ruling Class (1896) he saw elite rule a fact of history. Elites exploit the ruled and seek to turn themselves into permanent elites. 
Oswald MOSLEY (1896-1980) British politician. Once a leading Labour figure. Founder and leader of British Union of Fascists. Imprisoned during the Second World War.

Charles MURRAY (b.1943) American conservative writer and thinker. Attempts to explain poverty and the creation of the 'underclass' in terms of welfare dependency and individual inadequacy. Major works: Losing Ground: American Social Policy (1950-1980) (1984), The Bell Curve (1995).

Benito MUSSOLINI (1883-1945) Italian Fascist leader and dictator (1922-43). Initially sceptical of Hitler, he allied Italy with Nazi Germany.

NAPOLEON I (Bonaparte) (1769-1821) French general and emperor (1804-14). Brought order to France after the Revolution. Conqueror of much of Europe. Supported expanding frontiers of human knowledge. Innovator in government and law. Major influence on nineteenth-century politics, even after his defeat, exile and death.

NAPOLEON III (Bonaparte) (1808-73) French emperor (1852-71). Nephew of Napoleon I. Overthrew the Second French Republic. Pursued expansionist foreign policy. Defeated by Germany in Franco-Prussian War (1870-71).

Sergei NECHAEV (1847-82) Russian revolutionary and apostle of terrorist violence. Major work: Revolutionary Catechism (1869).

Sir Isaac NEWTON (1642-1727) English scientist and mathematician. Discoverer of the laws of gravity.

Friedrich NIETZSCHE (1844-1900) German philosopher, writer and essayist. Major European thinker. Great believer in the importance of 'Will' in history and society, and the role of strong individuals. Ideas picked up and misused by Nazis. Major works: Thus Spoke Zarathustra (1883-4), Beyond Good and Evil (1886), Ecce Homo (1908), The Will to Power (1901).

Steven NORRIS (b.1945) British Conservative politician of liberal views. MP (1983-97).

Robert NOZICK (1938-2002) American philosopher and politics academic. Great influence on New Right politics. Supporter of minimal state and minimal intervention. Strong defence of property rights should be the basis of government and society. Major work: Anarchy, State and Utopia (1974).

Michael OAKESHOTT (1901-90) British conservative political philosopher. Very influential thinker on modern New Right. Stressed important role of civil associations to underline his support for a limited role for the state. Major works: Rationalism in Politics and Other Essays (1962), On Human Conduct (1975).

George ORWELL, Eric Blair (1903-50) British socialist, journalist and novelist. Major political novels were Animal Farm (1945) and Nineteen Eighty-Four (1949).

Mosei OSTROGORSKI (1854-1919) Russian political scientist. Argued that modern political parties were controlled by senior figures who undermined democratic influence of individual members. Major work: Democracy and the Organisation of Political Parties (1902). 
Robert OWEN (1771-1858) British utopian socialist, philanthropist and wealthy selfmade manufacturer. Challenged laissez-faire economic doctrines. Influential on development of co-operative movement and British socialism. Experimented in new forms of economic and social life at New Lanark (Scotland) and New Harmony (USA).

Thomas PAINE (1737-1809) British political writer and radical. Supported and was personally involved in American Revolution and French Revolution. Personally involved in both. Stressed egalitarianism and individual freedom. Influential on both socialism and liberalism. Major works: The Rights of Man (1791/2), The Age of Reason (1794).

Matthew PARRIS (b.1949) British broadcaster and journalist. Once a Conservative MP.

Sir Robert PEEL, Second Baron (1788-1850) British Conservative politician and statesman. Held several Cabinet posts, including home secretary where he established the police force. Repealed Corn Laws (1846). Supported Catholic Emancipation (1829). Prime minister (1834-35, 1841-46).

\section{PERICLES (c.490-429Bc) Athenian statesman.}

Philippe PÉTAIN (1856-1951) French general and politician. Hero in the First World War. President of the Vichy regime which collaborated with Nazi Germany (1940-44). Imprisoned after the Second World War.

General Augusto PINOCHET (b.1915) Chilean general and politician. Overthrew elected government of Salvador Allende (1973). President of Chile (1973-98).

PLATO (427-347Bc) Athenian philosopher. Pupil of Socrates and teacher of Aristotle. Founded a university in Athens, the Academy. Writings are one of the most influential collections in history. Often seen as founding philosophy. His major works are Republic and Laws. The former advocates a structured society with trained specialists as political leaders. Major influence on the early development of Christianity and on Western culture.

Georgii V. PLEKHANOV (1856-1918) Russian Marxist thinker. Invented term 'dialectical materialism'. Introduced Marxism into Russian revolutionary movements.

Sir Karl R. POPPER (1902-94) British philosopher of Austrian descent. Defender of liberal values and scientific thought. Opponent of Nazism and communism. Very influential on neo-liberalism in the 1970s and 1980s. Major works: The Open society and Its Enemies (1945), The Poverty of Historicism (1957), The Logic of Scientific Discovery (1959).

Michael PORTILLO (b.1953) British Conservative politician.

Enoch POWELL (1912-98) British Conservative and, later, Unionist politician on the right of the party. Strongly opposed non-white immigration into Britain. Opposed Britain's membership of the European Union. Suspicious of US power in the world.

Pierre-Joseph PROUDHON (1809-65) French socialist and anarchist thinker. Early writings stress a strong opposition to the state. Later writings see role for a very minimal state. Major works: System of Alternative Economics (1846), What is Property? (1840), The Federal Principle (1863).

Samuel von PUFENDORFF (1632-94) German writer on law. Major work: Of the Law and Nature of Nations (1672). 
Thomas RAINSBOROUGH (d.1648) English soldier and republican advocate during the Civil War.

John RAWLS (1921-2002) American political philosopher. Very influential thinker on liberalism and social democracy. Major works: A Theory of Justice (1970), Political Liberalism (1993).

Ronald REAGAN (b.1911) Thirty-ninth president of the USA (1981-89). Presided over massive US military build-up and record federal budget deficit. But instrumental in helping to bring Cold War to an end in the 1980s.

David RICARDO (1772-1823) British economist, politician and stockbroker. Political radical. Founder of classical school of political economy. Major work: Principles of Political Economy and Taxation (1817).

Oscar ROMERO (1917-80) Salvadorean Roman Catholic bishop and Nobel Prize winner (1979). Murdered after speaking out in favour of the poor.

Jean-Jacques ROUSSEAU (1712-78) French political philosopher and educational theorist. Offended French government. Major intellectual influence on French Revolutionary thought. Belief in natural human goodness and the corrupting influence of civilisation on human nature. Wide impact on socialist, liberal, anarchist and fascist ideas. Concept of the 'General Will' a basis for democracy and totalitarianism. Major works: The Social Contract (1762), Emile (1762), Confessions (1770).

Salman RUSHDIE (b.1947) British novelist and journalist. Offended orthodox Muslims by his The Satanic Verses (1988) and subsequently went into hiding after death threats.

John RUSKIN (1819-1900) British author, social philosopher and art critic; established the Pre-Raphaelites. Founded Ruskin College, Oxford, for working people. Highly critical of capitalist industrialism and its damaging impact on beauty, sound social relationships and misuse of wealth.

Claude, Comte de SAINT-SIMON (1760-1835) French aristocrat and socialist. With Robert Owen and Charles Fourier, Saint-Simon is seen as one of the founding fathers of socialism. Stressed importance of application of knowledge to solution of social problems.

Lord SALISBURY, Robert Arthur Salisbury, Third Marquess (1830-1903) British Conservative politician and statesman. Held numerous senior government posts. Prime minister (1885-86, 1886-92, 1895-1902).

Michael SANDEL (b.1953) Contemporary American professor of government. Communitarian thinker, one of several who have stressed the failings of liberal individualism. Has written many books on politics and democracy. Major work: Liberalism and the Limits of Justice (1982).

Hjalmar SCHACHT (1877-1970) Nazi German finance minister.

Fritz SCHUMACHER (1911-77) British-German environmental theorist, conservationist and economist. Stress on importance of self-help technology for developing nations. Major work: Small is Beautiful: Economics As If People Mattered (1973). 
Joseph Alois SCHUMPETER (1883-1950) Austrian-American sociologist and economist. Stress on the role of the innovative capitalist in economic change. 'Creative destruction' is at heart of capitalism. Major works: Theory of Economic Development (1912), Business Cycles (1939), Capitalism, Socialism and Democracy (1942).

Roger SCRUTON (b.1944) British Conservative philosopher and historian of philosophy.

Claude de SEYSSEL (c.1510) Councillor to King Louis XII of France.

George Bernard SHAW (1856-1950) Irish playwright, commentator and wit. Member of Fabian society.

Samuel SMILES (1812-1904) British doctor and writer. Advocate of individual effort and initiative as outlined in biographies of great engineers and, chiefly, Self Help (1859).

Adam SMITH (1723-90) British economist. In The Wealth of Nations (1776) he outlined the basic theory of free-market economics. Of considerable influence on the development of nineteenth-century liberalism and modern neo-liberalism.

John SMITH (1938-94) British Labour politician and leader 1992-1994.

Georges SOREL (1847-1922) French supporter of revolutionary violence. Very influential on fascist thinking. Major work: Reflections on Violence (1905).

Herbert SPENCER (1820-1903) British philosopher and journalist. Supporter of evolutionary concepts. Major work: Principles of Psychology (1855) and Man Versus the State (1884).

Baruch SPINOZA (1632-77) Dutch philosopher. Major writings are on religion and ethics.

Joseph STALIN, Joseph Djugeshvili (1879-1953) Soviet leader (1924-53) and dictator. Developed concept of 'Socialism in One Country' and shaped Marxist theory to suit his own grip on power. Industrialised USSR in 1930s. Massive purges of real and imagined opponents in 1930s under 'The Terror'. Deal with Nazi Germany in August 1939 did not prevent the USSR being attacked in 1941. War leader in Second World War. Spread communist control over a number of states in Eastern Europe.

Max STIRNER, real name Johann Casper Schmidt (1806-56) German philosopher. Influential on Marx and individualist anarchism. Major work: The Ego and His Own (1845).

R. H. TAWNEY, Richard Henry (1880-1962) British socialist, educator and economic historian. Active in trade union and Labour movement. One of first critics of an affluent society. Believed that capitalism created moral disorder. Major works: Religion and the Rise of Capitalism (1926), The Acquisitive Society (1921), Equality (1931).

Harriet TAYLOR (1807-58) British feminist. Wife of J. S. Mill. Influenced his views on female suffrage.

Margaret H. THATCHER (b.1925) British politician. Leader of Conservative Party (1975-90). Supporter of neo-liberal and New Right policies for social reform. 
Alexis de TOCQUEVILLE (1805-59) French aristocrat, liberal historian, sociologist and politician. Very influential thinker on the problems of democracy. Author of Democracy in America (1835 and 1840).

Leo TOLSTOY (1828-1910) Russian aristocrat, novelist and pacifist. Writer of considerable eminence. Chief works: War and Peace (1863-9), Anna Karenina (1873-7).

Destutt de TRACEY (1754-1836) French philosopher. Invented term 'ideology' as the science of ideas.

Leon TROTSKY, Lev Davidovich Bronstein (1879-1940) Russian revolutionary and opponent of Stalin. Supporter of concept of global revolutionary movement for socialism. Murdered by Stalin's agent in 1940.

Franjo TUDJMAN (1922-99) Croatian president (1990-99). Academic historian and Croatian nationalist. Declared Republic of Croatia independent of Yugoslavia (1992).

Graham WALLAS (1858-1932) British socialist and political psychologist. Stressed the irrational forces that influence politics. Major works: Human Nature and Politics (1908), The Great Society (1914).

Michael WALZER (b.1935) American academic in politics, history, moral philosophy, concepts of the just war and the welfare state.

Barbara WARD (1914-81) and Rene DUBOS (1901-82) Ward was a British economist, journalist and conservationist, Dubos an American-French genetic scientist. Authors of Spaceship Earth (1966) and Only One Earth: The Care and Maintenance of a Small Planet (1972).

Beatrice WEBB (1858-1943) and Sidney WEBB, Baron Passfield (1859-1947) Leading British members of the Fabian Society, researchers in economic and social history, and campaigners for social reform.

Max WEBER (1864-1920) German sociologist. Major theorist of social class, bureaucracy and development of capitalism. Believed that he was modernising Marxism although usually seen as challenging it. Major work: The Protestant Ethic and the Spirit of Capitalism (1904-5).

Ann WIDDECOMBE (b.1947) British Conservative politician and novelist.

Harold WILSON, Baron Wilson of Rievaulx (1916-95) British Labour politician, academic and writer. Cabinet minister in post-war Labour Government. Labour leader (1963-75). Prime minister (1964-70 and 1974-76). Author of a number of books on British politics and Cabinet government.

Thomas Woodrow WILSON (1856-1924) 27th US President (1913-21). Liberal and idealist politician. Took USA into the First World War. At Versailles Peace Conference pressed for national self-determination and the League of Nations. Introduced women's suffrage.

Gerrard WINSTANLEY (1609-after 1660) English radical pamphleteer. Leader of the Diggers movement for land reform. Influential on socialist ideas. Major work: The Laws of Freedom in a Platform (1652). 
Mary WOLLSTONECRAFT (1759-97) British early feminist and campaigner for women's rights. Major work: A Vindication of the Rights of Woman (1792).

William WORDSWORTH (1770-1850) British poet. Particularly associated with Lakeland and the Romantic movement. Major works: Lyrical Ballads (1798), The Prelude (1850), 'Intimations of Immortality from Recollections of Early Childhood' (1807). 